certain restrictions necessarily observed by Government departments. Much of the work was done co-operatively with the agricultural departments of Provincial Governments. The scheme of work was conceived on broad and public-spirited lines; the Company cannot hope to recover its expenditure by any immediate increase in sales of oil; the most it can expect is to share, in common with other industries, in the increased general prosperity that will accompany any lasting improvement in the agricultural conditions of rural India. Although the greater proportion of Indian cultivators farm under peasant conditions, and cannot directly take up power farming, the question of co-operative use is worthy of attention; in addition, there seems a much larger scope for heavy power machinery on large holdings, for example, planters' estates, and in the reclamation and improvement, under Govern. ment supervision, of large areas. The report deals in detail with an extensive series of experiments on weed eradication by deep cultivation, on contract ploughing and on the analysis of costing data. The concluding chapters are devoted to a discussion of the design and performance of tractors and cultivation implements in relation to Indian conditions, and to the organisation of contract tractor ploughing.

\section{Annual Report of Cheshunt Experimental Station}

THE twentieth Annual Report (1934) of the Experimental and Research Station of the Nursery and Market Garden Industries Development Society, Ltd, has recently been published, from the Station, Turner's Hill, Cheshunt, Herts (pp. 107). The experimental work for 1934 is a continuation of the previous trials of varieties, fertilisers, soil heating, methods of sterilisation and other practices. Mycological investigations include a considerable section on virus diseases, and studies of fungi which attack chrysanthemums, roses, lettuce, carnations and other crops. A new insect parasite of the tomato moth caterpillar has been further described, pests of lettuce and chrysanthemum have received special study, whilst the more common thrips, symphilids and woodlice have also had attention. Insecticide and fungicide investigations have been continued, and the chemists have inquired into the potash content of 'blotchy' tomatoes and the manurial nutrition of chrysanthemums. The effects of light and water content on the growth of tomato plants, with studies on vernalisation, form the main subjects of physiological interest.

\section{Use of Radium in Ireland}

The Irish Radium Committee has issued its report for the year 1934 (Sci. Proc. Roy. Dublin Soc., 21, No. 25, 1935. Separate issue). There was a small increase in the number of batches of radon tubes issued; but a decrease in the total quantity of radon, owing to the continued tendency towards the use of smaller doses, and a considerable increase in the number of cases treated. Little can be gathered from the report of the success or otherwise of the treatment, and an unsatisfactory feature is the fact that some 25 per cent of the patients treated could not be traced after their discharge from hospital.

\section{Prof. P. O. Pedersen}

THe friends of Prof. P. O. Pedersen, principal and professor of electrotechnics of the Royal Technical College, Copenhagen, have published in English some of his papers written in Danish to commemorate his sixtieth birthday, which occurred on June 19, 1934. The subjects discussed are mainly on the development of electrical communication technique, with special reference to contributions by Danes. Excellent work has been done by Gulstad, L. Lorenz, Jensen, C. E. Krarup, Johnsen and Rahbek, Valdemar Poulsen and Prof. Størmer. In a lecture delivered in 1933, Pedersen discusses the possibility of an application of scientific technical methods to other fields of research. The last paper given is on the depreciation of public utilities. In an appendix, a list is given of 97 publications by Pedersen.

\section{New Discoveries of Permian Insect Fossils}

According to Science Service, Washington, D.C., an extensive deposit of fossil insects has been brought to light in a sandstone stratum near the mouth of the Mezer River on the Arctic coast of the U.S.S.R. A preliminary study of these remains has been made by Prof. A. G. Martynov, who finds that all Palæozoic families of insects are represented. Cockroaches are most abundant, but grasshoppers, dragonflies, scorpion flies and other primitive insect groups are also well represented, together with a small number of Coleoptera. An expedition of the Russian Academy of Sciences is at present making collections and studies in the region mentioned. It appears that these insect beds are contemporaneous with the well. known insect-bearing strata of Kansas, which have yielded an abundant fauna.

\section{Japanese Biological Publications}

WE have received vol. 3 , Nos. 1 and 2 of Botany and Zoology, Theoretical and Applied, from Japan. It is a monthly publication, and these two numbers contain 364 and 176 pages respectively. The papers are illustrated and cover every phase of biology, but with the exception of one paper by Prof. Crozier, of Harvard University, they are entirely in Japanese. Only the scientific names and the names of Western authors are given in European characters, except one paper printed in Japanese using the Western alphabet ! It seems a pity that papers, many of which are evidently of considerable general interest, should thus be cut off from Western science. Even Esperanto, which is occasionally being used by the Japanese in their scientific publications, would be preferable as a medium of publication if it is intended to attract the interest of biologists outside Japan.

\section{Scientific Research in Australia}

THE eighth annual report of the Commonwealth of Australia Council for Scientific and Industrial Research shows an increasing range of investigation and a growing number of requests for assistance 